\title{
Non-caloric sweeteners: specific characteristics and safety assessment
}

\author{
Brian M. Cavagnari, M.D., PhD ${ }^{a}$
}

\begin{abstract}
Non-caloric sweeteners are food additives that can be added to food and beverages, in substitution of sugar, thus allowing to decrease energy content and free sugars intake. However, many health care professionals have questioned the safety of these additives for human consumption. Therefore, it is crucial that health care professionals become familiar with the characteristics of each non-caloric sweetener (chemical structure, absorption profile, metabolism, and route of excretion) and with the findings of the detailed safety assessments done prior to their approval, so that they can be a reliable source of scientific information for their patients.

The purpose of this article is to provide a better understanding of the safety assessment process of non-caloric sweeteners prior to their approval, which includes determining the non-observed adverse effect level and the acceptable daily intake.

Key words: non-caloric sweeteners, acce ptable daily intake, safety.

http: / / dx.doi.org/10.5546/ aap.2019.eng.e1
\end{abstract}

To cite: Cavagnari BM. Non-caloric sweeteners: specific characteristics and safety assessment. Arch Argent Pediatr 2019;117(1):e1-e7.

a. School of Nutrition, Faculty of Medical Sciences, Pontificia Universidad Católica Argentina. Center for Nutrition Research (Centro de Investigaciones Nutricionales, CINUT),

Autonomous City of Buenos Aires, Argentina.

E-mail address:

Brian M. Cavagnari,

M.D.: bcavagna@gmail. com

Funding:

None.

Conflict of interest:

See page e6.

Received: 11-8-2017

Accepted: 6-4-2018
24 kilograms of sugar per person per year. $^{2}$

It is highly difficult to fulfill the population's preferences for sweetness and comply with the WHO's health recommendations in relation to free sugars. A tool that has been made available to reach this goal is the use of non-caloric sweeteners (NCSs).

NCSs are food additives that can be added to food and beverages, in substitution of sugar, to decrease the energy content while maintaining palatability and sweetness. ${ }^{3,4}$

Although all NCSs share the ability to induce perceptions of sweetness, they have very different chemical structures (Table 1), absorption profiles (Table 2), metabolism (Tables 3 and 4), and routes of excretion. Therefore, it is incorrect to extrapolate the biological effects observed for a specific NCS to all NCSs in general.

The NCSs included in this review are some of those known as intensive sweeteners because they are many times sweeter than sucrose (Table 1), so very small amounts are required in food or beverages. ${ }^{4}$ Therefore, the amount of NCSs and their absorbed, metabolized or excreted metabolites will also be very low compared to bulk sweeteners, such as sugar.

It is worth noting that, before the regulatory approval of a NCS, extensive studies are conducted to understand the biological fate of each of these NCSs in the body. However, and although there is a large body of evidence on NCS safety, as well as assessments made by government agencies and international authorities in relation to food safety, both health care professionals and the general population have questioned the safety of NCSs for human consumption. ${ }^{7}$

Therefore, it is crucial that health 
care professionals become familiar with the metabolism of NCSs and the findings of the detailed safety assessments conducted prior to their approval, so that they can be a reliable source of scientific information for their patients.

The objective of this review is to provide a better understanding of the safety assessment process of the most commonly used NCSs (acesulfame-K, aspartame, saccharin, sucralose, and steviol glycosides) before their approval, including the determination of the non-observed adverse effect level (NOAEL) and the acceptable daily intake (ADI). Studies related to the post- marketing effects will not be considered here and will be the subject of another publication.

\section{Estimation of the non-observed adverse effect level}

The regulatory approval of NCSs at an international level is based on the scientific recommendation of the Joint FAO/WHO Expert Committee on Food Additives (JECFA).

All NCSs used at present have been subjected to very detailed safety assessments prior to their approval. ${ }^{9,19,20}$ These safety tests are done in animals because, for ethical reasons, they cannot

TABLE 1. Chemical structure and relative sweetness of various non-caloric sweeteners

\begin{tabular}{|c|c|c|}
\hline Non-caloric sweetener & Type of compound & Relative sweetness* \\
\hline Saccharin & 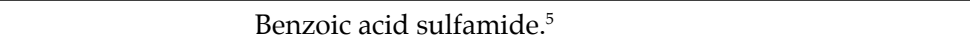 & 300 \\
\hline \multirow{2}{*}{\multicolumn{2}{|c|}{$\begin{array}{l}\text { Potassium salt of 6-methyl-1,2,3-oxathiazine-4(3H)-one-2,2-dioxide. }{ }^{6} \\
\text { Chlorinated disaccharide }\end{array}$}} & 200 \\
\hline (1,6-dichloro & & 600 \\
\hline \multicolumn{2}{|c|}{$\begin{array}{l}\text { Steviol glycosides (stevia) } \begin{array}{c}\text { Glycosylated diterpenes. Several steviol glycosides } \\
\text { have been isolated in S. rebaudiana leaves }\end{array} \\
\text { (stevioside and rebaudiosides A, D, B, and M, among others). } \\
\text { All steviol glycosides contain a common chemical core: steviol. }{ }^{8}\end{array}$} & $200-300$ \\
\hline Aspartame & yl ester of a dipeptide made up of L-aspartic acid and L-phenylalanine. ${ }^{9}$ & 200 \\
\hline
\end{tabular}

* Relative sweetness: compared to sucrose (value $=1$ ).

TABLE 2. Absorption profile of various non-caloric sweeteners

\begin{tabular}{|c|c|}
\hline Non-caloric sweetener & Absorption \\
\hline Saccharin & It is extensively absorbed as the intact molecule. ${ }^{10}$ \\
\hline Acesulfame-K & It is extensively absorbed as the intact molecule. ${ }^{6}$ \\
\hline Sucralose & Most of it ( $85 \%)$ is not absorbed, $15 \%$ is absorbed as the intact molecule. ${ }^{7}$ \\
\hline Steviol glycosides (stevia) & Only the steviol metabolite from the different steviol glycosides is absorbed. . $^{11,12,13}$ \\
\hline Aspartame & $\begin{array}{l}\text { Aspartame is not absorbed as such but it is completely broken down into phenylalanine, } \\
\text { aspartate, and methanol, which are ultimately absorbed.,14,15 }\end{array}$ \\
\hline
\end{tabular}

TABLE 3. Metabolism of various non-caloric sweeteners

Non-caloric sweetener
Saccharin
Acesulfame-K
Sucralose
Steviol glycosides (stevia)

Steviol glycosides (stevia)

\author{
Metabolism \\ It is not metabolized. ${ }^{10,16}$ \\ It is not metabolized. ${ }^{6,17}$ \\ It is not metabolized. ${ }^{7}$ \\ Steviol glycosides are not metabolized by human enzymes but only by the gut \\ microbiota bacteria. \\ The only resulting metabolite, steviol, is absorbed and conjugated in the liver to \\ facilitate excretion. ${ }^{11-13}$ \\ Aspartame is broken down into methanol, phenylalanine, and aspartate, \\ which are metabolized in the same way as when they come from the breakdown of fruits, \\ vegetables, and high-protein foods..$^{9,14,15}$
}

Aspartame

NOTE: In all cases, elimination is rapid, and no NCS or metabolite bioaccumulation is observed in the body. ${ }^{7}$ 
be conducted in humans. In these tests, increasing concentrations of the NCS are used under study so as to detect the potential adverse effects caused by the different additive doses.

The highest doses are used to ensure the identification of potential adverse effects. The lowest levels are used to identify the maximum daily dose at which no adverse effects occur, known as the "NOAEL."

Therefore, the NOAEL is the amount of additive -consumed in daily doses in long-term studies-, which shows no adverse effects in animals. ${ }^{7}$

\section{Estimation of the acceptable daily intake}

The ADI is calculated by applying a safety factor of 100 to the NOAEL; such factor is established by regulatory agencies to account for differences among species (studies are done in animals, not in humans) and to ensure the protection of the most susceptible members of the population, i.e. children, pregnant women, and elderly subjects. This means that the ADI is estimated by dividing the NOAEL by 100 .

This level, which is 100 times lower than the NOAEL, ensures a wide safety margin for NCS consumption because the maximum additive intake approved will be 100 times lower than that which did not cause adverse effects in prior assessments.

For example, if the amount of an NCS that has demonstrated no adverse effects in animal studies for daily consumption during most of an animal's lifespan is $4000 \mathrm{mg}$ per kilogram of body weight per day, the NOAEL will be $4000 \mathrm{mg} / \mathrm{kg}$ / day. By applying a safety factor of 100, the ADI will be $40 \mathrm{mg} / \mathrm{kg} /$ day.

Ultimately, to establish the ADI, the amount that showed no adverse effects is reduced 100 times. This safety factor is much higher than that existing for most nutrients and natural food components. Therefore, the ADI is a daily intake level that is considered safe for everyone, including those with the highest potential

TABLE 4. Metabolism of the different aspartame breakdown products

\begin{tabular}{|c|c|}
\hline Aspartame breakdown products & Metabolism \\
\hline Methanol & $\begin{array}{l}\text { It enters portal circulation and is metabolized to formaldehyde by } \\
\text { alcohol-dehydrogenase. This is oxidized to formic acid by formaldehyde- } \\
\text { dehydrogenase. Formic acid is excreted in urine or metabolized to carbon dioxide } \\
\text { and leaves the body through breathing. }{ }^{9}\end{array}$ \\
\hline Aspartate & $\begin{array}{l}\text { It turns into oxaloacetate by transamination. Then it reaches portal circulation and } \\
\text { becomes part of the reservoir of free amino acids. Oxaloacetate and aspartate are } \\
\text { interconverted and may participate in the urea cycle and gluconeogenesis. } \\
\text { Aspartate may also be used to produce other essential amino acids, such as methionine, } \\
\text { threonine, isoleucine, and lysine. Finally, excess aspartate is excreted in urine. }{ }^{18}\end{array}$ \\
\hline Phenylalanine & $\begin{array}{l}\text { It enters the liver through portal circulation, where it may be partially turned into } \\
\text { tyrosine by phenylalanine hydrolase. }{ }^{19} \text { Phenylalanine reaching systemic circulation may } \\
\text { be distributed throughout the body, including the brain, where it is necessary for } \\
\text { normal growth and development. } 9 \text { It may also turn into tyrosine and, finally, } \\
\text { into dopamine, norepinephrine, and epinephrine. } \\
\text { Excess phenylalanine intake is excreted in urine. }\end{array}$ \\
\hline
\end{tabular}

TABLE 5. Acceptable daily intake of various non-caloric sweeteners (JECFA)

\begin{tabular}{lcc}
\hline Non-caloric sweeteners & $\begin{array}{c}\text { Acceptable daily intake } \\
\text { (mg/kg of body weight/day) }\end{array}$ \\
\hline Acesulfame-K & 15 \\
Aspartame & 40 \\
Saccharin & 5 & 15 \\
Sucralose & $4^{*}$ \\
Steviol glycosides (stevia) & \\
\hline
\end{tabular}

JECFA: Joint FAO/WHO Expert Committee on Food Additives.

* Since all steviol glycosides are metabolized to a common final metabolic product (steviol), the JECFA established an ADI

"for all steviol glycosides" based on the amount of steviol produced by each steviol glycoside after hydrolysis, called "steviol equivalents." The ADI was set at $4 \mathrm{mg}$ of steviol equivalents per kilogram of body weight per day. ${ }^{21}$ For example, this would be equivalent to an ADI of $12 \mathrm{mg} / \mathrm{kg} /$ day for rebaudioside A. 
exposure to a food additive. ${ }^{7}$

The ADI is the most important tool to warrant an appropriate and safe use of NCSs. The ADI for each NCS is shown in Table 5.

Using the ADI to assess the safety and toxicity of food additives has been accepted by regulatory authorities worldwide. ${ }^{7}$

Since the ADI is estimated considering consumption during a lifetime, it provides a sufficiently ample safety margin to avoid becoming alarmed if an individual's short-term intake exceeds the ADI levels, as long as the average, long-term intake does not. ${ }^{22-25}$

\section{Usual exposure to non-caloric sweeteners}

Before approving a NCS, potential exposure in people with a higher intake is estimated considering the data from food intake surveys and the levels proposed for such NCS in different types of food and beverages.

This way, the maximum use levels for different food categories are established so as to ensure that individuals with higher intake levels do not exceed the ADI. The usual population NCS intake is below the ADI. ${ }^{7}$

\section{Characteristics of various non-caloric sweeteners}

Acesulfame potassium (acesulfame-K)

Acesulfame- $\mathrm{K}$ is a widely used NCS, in general, combined with other NCSs. At present, it is authorized in over 90 countries.

The stability of acesulfame-K in food, especially its resistance to thermal degradation, makes it a very attractive option for its use in food and beverages. ${ }^{6,26}$

Acesulfame-K is a hydrophilic compound that, once ingested, is rapidly and almost completely absorbed into the systemic circulation. ${ }^{6,17}$ Once absorbed, it is distributed to all body tissues through blood.

Studies in humans have demonstrated that acesulfame- $\mathrm{K}$ is not metabolized before renal excretion, within 24 hours after intake. ${ }^{6,27}$

\section{Aspartame}

Aspartame is a widely used NCS worldwide as tabletop sweetener and in a broad variety of food and beverages.

Its calorie content per gram is similar to that of sucrose (4 calories per gram), but since using a very small amount achieves the level of sweetness required, products containing it practically provide no calorie intake.
Aspartame has been approved by the JECFA, the Food and Drug Administration (FDA), and other prestigious regulatory agencies in over 110 countries. ${ }^{18,28}$

After consumption, aspartame is broken down by enzymatic action (esterases and peptidases) into its three main components: methanol (10\% by aspartame weight), aspartic acid (40\%), and phenylalanine $(50 \%)$. Nothing of the intact aspartame reaches circulation. ${ }^{9,14,15}$ Only the three breakdown products reach the bloodstream and are found in the same form as when absorbed from food sources, such as fruits, vegetables, and proteins, e.g., meat, fish, eggs or legumes. ${ }^{7}$

In the body, the three breakdown products take the usual metabolic routes: they are absorbed into the tissues or excreted (Table 4).

\section{Saccharin}

In humans, absorbed saccharin binds reversibly to plasma proteins and is distributed to body organs through blood. Between $85 \%$ and $95 \%$ of absorbed saccharin is excreted in urine. The rest is excreted in feces. ${ }^{10,16}$

\section{Sucralose}

Sucralose is obtained by the selective halogenation of sucrose: it is produced from sucrose by replacement of the three hydroxyl groups at positions $4,1^{\prime}$ and $6^{\prime}$ by chlorine, thus obtaining 4,1', $6^{\prime}$-trichlorogalactosucrose. Such change results in a modification of the molecule structure, so that the glycosidic enzymes that hydrolyze sucrose are unable to separate sucralose. Therefore, sucralose is not broken down into monosaccharides or metabolized by the body to obtain energy; it does not provide calories or affect blood glucose levels. ${ }^{7}$

Sucralose is poorly absorbed, its metabolism is little and is mostly excreted unchanged in feces. ${ }^{7}$

It is stable at high temperatures, so it is considered the ideal sweetener for beverages and other types of food, including those subjected to heat treatment, such as baked products.

\section{Steviol glycosides (stevia)}

Stevia leaf extract is a NCS that comes from the Stevia rebaudiana (Bertoni) plant, which contains sweet taste compounds called "steviol glycosides" (stevio side and rebaudiosides A, D, B, M, etc.). 29,30

The enzymes and acids present in the upper gastrointestinal tract do not hydrolyze steviol glycosides; however, they are all metabolized to a common final product, steviol, by gut 
bacteria. ${ }^{11-13,31-33}$

Instead, steviol is resistant to bacterial breakdown ${ }^{12}$ and is absorbed, glucuronized in the liver, and transported through the bile back into the intestinal tract, where it is finally excreted. ${ }^{7}$

In humans, the main metabolite is steviol glucuronide, which is mostly excreted in urine. ${ }^{32,34}$

\section{Metabolic aspects of non-caloric sweeteners in relation to pregnancy and breastfeeding Acesulfame-K}

This NCS can be transported through the placenta and detected in low levels in fetal tissues. ${ }^{35}$ Placental levels are higher than fetal ones so the placenta acts as a protective barrier. Maternal exposure to acesulfame-K does not pose a risk for the fetus. ${ }^{7}$

Low levels of acesulfame-K have been reported in human breast milk, although the level detected is several orders of magnitude below the ADI. ${ }^{36}$

\section{Aspartame}

Due to the rapid breakdown of aspartame in the gastrointestinal lumen and in the intestinal mucosa cells before reaching the bloodstream, the intact aspartame molecule is never present in body tissues or breast milk.9,18

There are no epidemiological or experimental data indicating that aspartame crosses the placental barrier or that maternal intake causes adverse events on the mother or the fetus. ${ }^{37,38}$ Actually, an intake above the ADI (up to $200 \mathrm{mg}$ / $\mathrm{kg}$ ) has not been associated with risks for fetal health. ${ }^{37,38}$

Aspartame is not found in the milk of breastfeeding women who consumed this NCS. ${ }^{36}$

\section{Sucralose}

There is no evidence that sucralose is transported through the placenta. ${ }^{7}$

\section{Saccharin}

Studies conducted in rodents have demonstrated that saccharin may cross the placenta and that, due to the slow fetal metabolism, it remains in fetal tissues longer than in those of adults. ${ }^{37,38}$

Saccharin may also be transported through the placenta and detected in human fetal tissues.

Based on the available evidence in animals and the lack of contradictory studies in humans, saccharin is not recommended during preconception and periconception. ${ }^{37,38}$

\section{Cyclamate}

Cyclamate crosses the placental barrier and is found in the amniotic fluid, which indicates that is reaches fetal tissues. ${ }^{39}$

Cyclamate is not recommended during pregnancy. ${ }^{37-39}$

To conclude, it may be stated that saccharin and cyclamate are not recommended during pregnancy. Other NCSs (aspartame, acesulfame-K, and sucralose) have not demonstrated to be unsafe during pregnancy when intake is below the ADI. ${ }^{37,38}$

\section{Aspartame and phenylketonuria}

The administration of $34 \mathrm{mg} / \mathrm{kg}$ of aspartame ( $99^{\text {th }}$ percentile of the intake) to patients with moderate phenylketonuria increased plasma phenylalanine to $16 \mathrm{mmol} / \mathrm{dL}$ compared to $11 \mathrm{mmol} / \mathrm{dL}$ in healthy adults. ${ }^{40,41}$

The administration of lower doses $(10 \mathrm{mg} /$ $\mathrm{kg}$ ) -which better reflect actual consumptionincreases phenylalanine plasma levels in healthy subjects to $6 \mathrm{mmol} / \mathrm{dL}$ (from $4.5 \mathrm{mmol} / \mathrm{dL}$ at baseline), whereas the level in heterozygous subjects for phenylketonuria reaches $8 \mathrm{mmol} / \mathrm{dL}$ (from $6.9 \mathrm{mmol} / \mathrm{dL}$ at baseline). ${ }^{42}$

The European Food Safety Agency (EFSA) has concluded that, in patients with phenylketonuria, the ADI for aspartame is not applicable because they require to strictly adhere to a low phenylalanine diet from all food sources, including aspartame. ${ }^{43}$

For this reason, aspartame-containing food labels should warn "Phenylketonurics - contains phenylalanine" or include a similar statement. ${ }^{44}$

\section{DISCUSSION AND CONCLUSIONS}

Many health care professionals generally refer to "NCSs" as if they were talking about the same compound, with the same chemical properties and metabolic targets. Although the different NCSs provide a sweet taste to food and beverages, it is very important to note that these are all different molecules. For this reason, the potential effects of a sweetener on health cannot be extrapolated to the rest.

In spite of the extensive safety assessments carried out prior to their approval and the full understanding of the absorption, distribution, metabolism, and excretion of the different NCSs, their safety has become controversial. This led many health care professionals to have doubts about whether or not to allow the intake of NCS-containing food and beverages, even when 
patients have diseases like obesity and diabetes.

Based on the toxicokinetic data of each NCS, the safety margin established by the ADI (with a safety factor that is 100 times lower than the maximum daily dose without adverse effects) and considering the low level of exposure to NCSs, such concern regarding NCS safety seems to be out of proportion.

\section{Conflict of interest}

The author has received consultancy fees and payments from several biotechnology, pharmaceutical, and food and beverage companies. He has also received unrestricted consultancy fees, payments, and research study funding from government sources and non-profit organizations. None of the agencies mentioned here participated or participates in the design or development of this manuscript.

\section{REFERENCES}

1. Organización Mundial de la Salud. Directriz: ingesta de azúcares para adultos y niños. Ginebra, Suiza: OMS; 2015. [Accessed on: November $8^{\text {th }}$, 2017]. Available at: http:/ / apps.who.int/iris / bitstream/10665/154587/2/WHO_ NMH_NHD_15.2_spa.pdf.

2. Sugar projections: consumption per capita. OECD-FAO 2015:32. [Accessed on: November $8^{\text {th }}$, 2017]. Available at: http: / / www.oecd-ilibrary.org/agriculture-and-food / oecd-fao-agricultural-outlook-2015/ sugar-projectionsconsumption-per-capita_agr_outlook-2015-table135-en.

3. Drewnowski A. Intense sweeteners and the control of appetite. Nutr Rev. 1995; 53(1):1-7.

4. Schmidt-Hebbel H. Avances en aditivos alimentarios y la reglamentación de los alimentos. Aplicaciones y comentarios de orden químico y tecnológico. Santiago de Chile: Universitaria; 1990.Pages 64-8.

5. Arnold DL, KrewskiD, Munro IC. Saccharin: a toxicological and historical perspective. Toxicology. 1983;27(3-4):179-256.

6. Klug C, von Rymon Lipinski GW. Acesulfame potassium. In: O'Brien Nabors L (Ed.). Alternative Sweeteners. 4th ed. Boca Raton, FL: CRC Press; 2012.Págs.13-30.

7. Magnuson BA, Carakostas MC, Moore NH, et al. Biological fate of low-calorie sweeteners. Nutr Rev. 2016; 74(11):67089.

8. Prakash I, Chaturvedula VS. Structures of some novel a-glucosyl diterpene glycosides from the glycosylation of steviol glycosides. Molecules. 2014; 19(12):20280-94.

9. Butchko HH, Stargel WW, Comer CP, et al. Aspartame: review of safety. Regul Toxicol Pharmacol. 2002; 35(2 Pt 2):S1-93.

10. Sweatman TW, Renwick AG, Burgess CD. The pharmacokinetics of saccharin in man. Xenobiotica. 1981; 11(8):531-40.

11. Hutapea AM, Toskulkao C, Buddhasukh D, et al. Digestion of stevioside, a natural sweetener, by various digestive enzymes. J Clin Biochem Nutr. 1997; 23(3):177-86.

12. Gardana C, Simonetti P, Canzi E, et al. Metabolism of stevioside and rebaudioside A from Stevia rebaudiana extracts by human microflora. J Agric Food Chem. 2003; 51(22):6618-22.

13. Koyama E, Kitazawa K, Ohori Y, et al. In vitro metabolism of the glycosidicsweeteners, stevia mixture and enzymatically modified stevia in human intestinal microflora. Food Chem Toxicol. 2003; 41(3):359-74.

14. Hooper NM, Hesp RJ, Tieku S. Metabolism of aspartame by human and pig intestinal microvillar peptidases. Biochem J. 1994; 298 Pt 3:635-9.

15. Stegink LD. Aspartame metabolism in humans: Acute dosing studies. In: Stegink LD, Filer LJ Jr (Ed.). Aspartame: Physiology and Biochemistry. New York, NY:Marcel Dekker; 1984.Pages 509-53.

16. Sweatman TW, Renwick AG. The tissue distribution and pharmacokinetics of saccharin in the rat. Toxicol Appl Pharmacol. 1980; 55(1):18-31.

17. Renwick AG. The metabolism of intense sweeteners. Xenobiotica. 1986; 16(10-11):1057-71.

18. European Food Safety Authority. Scientific Opinion on the re-evaluation of aspartame (E 951) as a food additive. EFSA J. 2013; 11(12):3496.

19. Bender DA. The aromatic amino acids: phenylalanine, tyrosine and tryptophan. In: Amino Acid Metabolism. 3rd ed. Chichester, UK: Wiley-Blackwell; 2012.Págs.32376.

20. Renwick AG. The intake of intense sweeteners - an update review. Food Addit Contam. 2006; 23(4):327-38.

21. Joint FAO/WHO Expert Committee on Food Additives. Steviol glycosides. In: Evaluation of Certain Food Additives. Geneva, Switzerland: World Health Organization; 2005. Pages 34-9.

22. Renwick AG. Intake of intense sweeteners. World Rev Nutr Diet. 1999; 85:178-200.

23. Renwick AG. Incidence and severity in relation to magnitude of intake above the ADI or TDI: use of critical effect data. Regul Toxicol Pharmacol. 1999; 30(2 Pt 2):S79-86.

24. Renwick AG. Toxicokinetics in infants and children in relation to the ADI and TDI. Food Addit Contam. 1998; 15(Suppl):17-35.

25. Renwick AG. Needs and methods for priority setting for estimating the intake of food additives. Food Addit Contam. 1996; 13(4):467-75.

26. Chattopadhyay S, Raychaudhuri U, Chakraborty R. Artificial sweeteners - a review. J Food Sci Technol. 2014; 51(4):611-21.

27. Joint FAO/WHO Expert Committee on Food Additives. 596: Acesulfame potassium. In: Toxicological Evaluation of Certain Food Additives. Geneva, Switzerland: World Health Organization; 1981. [Accessed on: June $6^{\text {th }}$, 2018]. Available at:http: / / www.inchem.org/documents/jecfa/jecmono/ v16je02.htm.

28. US Food and Drug Administration. FDA statement on European aspartame study. Washington, DC., 2007. [Accessed on: November $\left.8^{\text {th }}, 2017\right]$. Available at: http:/ / www.fda.gov/Food/IngredientsPackagingLabeling/ FoodAdditivesIngredients/ucm208580.htm.

29. Prakash I, Chaturvedula VS, Markosyan A. Isolation, characterization and sensory evaluation of a hexa betaD-glucopyranosyl diterpene from Stevia rebaudiana. Nat Prod Commun. 2013; 8(11):1523-6.

30. Joint FAO/WHO Expert Committee on Food Additives. Compendium of Food Additive Specifications. Rome, Italy: Food and Agriculture Organization of the United Nations; 2010. [Accessed on: June $6^{\text {th }}, 2018$ ]. Available at: www.fao. org/docrep/013/i1782e/i1782e.pdf.

31. Carakostas MC, Curry LL, Boileau AC, Brusick DJ. Overview: the history, technical function and safety of rebaudioside A, a naturally occurring steviol glycoside, for use in food and beverages. Food Chem Toxicol. 2008; 46(Suppl 7):S1-10.

32. Wheeler A, Boileau AC, Winkler PC, et al. Pharmacokinetics of rebaudioside $\mathrm{A}$ and stevioside after single oral doses in 
healthy men. Food Chem Toxicol. 2008; 46(Suppl 7):S54-60.

33. Wingard RE Jr, Brown JP, Enderlin FE, et al. Intestinal degradation and absorption of the glycosidic sweeteners stevioside and rebaudioside A. Experientia. 1980;36(5):51920.

34. Geuns JMC, Buyse J, Vankeirsbilck A, et al. Identification of steviol glucuronide in human urine. J Agric Food Chem. 2006; 54(7):2794-8.

35. Joint FAO/WHO Expert Committee on Food Additives. 720: Acesulfame potassium. In: Toxicological Evaluation of Certain Food Additives. Geneva, Switzerland: World Health Organization; 1991. [Accessed on: June $6^{\text {th }}$, 2018]. Available at:http: / / www.inchem.org/documents/jecfa/jecmono/ v28je13.htm.

36. Sylvetsky AC, Gardner AL, Bauman V, et al. Nonnutritive sweeteners in breast milk. J Toxicol Environ Health A. 2015; 78(16):1029-32.

37. Gougeon R, Spidel M, Lee K, et al. Canadian Diabetes Association National Nutrition Committee Technical Review: Non-nutritive intense sweeteners in diabetes management. Can J Diab. 2004; 28(4):385-99.

38. Calzada-León R, Ruiz-Reyes M, Altamirano-BustamanteN, Padrón-Martínez MM. Características de los edulcorantes no calóricos y su uso en niños. Acta Pediatr Mex. 2013; 34(3):141-53.
39. Durán Agüero S, Salazar C, Espinoza J, Fuentealba F. ¿Se pueden recomendar en el embarazo los edulcorantes no nutritivos? Rev Chil Nutr. 2017; 44(1):103-10.

40. Stegink LD, Filer LJ, Baker GL, McDonnell JE. Effect of aspartame loading upon plasma and erythrocyte amino acid levels in phenylketonuric heterozygotes and normal adult subjects. J Nutr. 1979; 109(4):708-17.

41. Stegink LD, Filer LJ Jr, Baker GL, McDonnell JE. Effect of an abuse dose of aspartame upon plasma and erythrocyte levels of amino acids in phenylketonuric heterozygous and normal adults. J Nutr. 1980; 110(11):2216-24.

42. Caballero B, Mahon BE, Rohr FJ, et al. Plasma amino acid levels after single-dose aspartame consumption in phenylketonuria, mild hyperphenylalaninemia, and heterozygous state for phenylketonuria. J Pediatr. 1986; 109(4):668-71.

43. European Food Safety Authority. EFSA completes full risk assessment on aspartame and concludes it is safe at current levels of exposure. 2013. [Accessed on: May 16 ${ }^{\text {th }}, 2018$ ]. Available at: https://www.efsa.europa.eu/en/press / news / 131210

44. Administración Nacional de Medicamentos, Alimentos y Tecnología Médica. Acerca de los edulcorantes que contienen aspartamo. [Accessed on: May 16 ${ }^{\text {th }}, 2018$ ]. Available at: http://www.anmat.gov.ar/Alimentos/ Aspartamo.pdf. 